Per-Arne Bodin, Vestments of a Russian Bishop. A Cultural Study, w: Szata liturgiczna, red. Adelajda Sielepin CHR, Jarosław Superson SAC, Kraków 2016, s. 87-108.

DOI: http://dx.doi.org/10.15633/9788374386029.06

Per-Arne Bodin

STOCKHOLM

\title{
Vestments of a Russian Bishop. A Cultural Study
}

The aim of the present article is to investigate from a cultural perspective the Russian Orthodox garment tradition, particularly the bishop's robes and dressing ritual. Its primary focus is the use and significance of these phenomena rather than their history. My methodology is based on Russian semiotics and the conviction that every component of a cultural tradition has something to contribute to our understanding of the entire culture. The vesting ceremony is almost identical for bishops, metropolitans or patriarchs, and it is the ritual as a whole that is of interest here.

In his memoirs, the Russian émigré Bishop Johann von Gardner recalls a scene from his childhood in I9I4 in which he witnessed the ceremony in the Uspenskij Cathedral in the Moscow Kremlin. Concluding the narrative he wrote much later in emigration he notes:

I marveled at the structured, measured, symmetrically synchronized movements of the subdeacons vesting the bishops. And again, in them as well, one sensed the traditions that had been established over the centuries, something inexpressible in words, the centuries-old tradition of our pious fathers. It was expressed in everything: in the movements of the clergy, and in how the people stood in church, and in how and what the choir sang. One had the sensation that here the best of the best had been assembled. Yes, this is unforgettable, and blessed is he who has seen and heard that beauty. Such glory and beauty no longer exists upon the earth!t

1 J. von Gardner, The Triumph of Orthodoxy, http://www.pravoslavie.ru/english/69I22. htm (July 6th 20I5). 
Shortly thereafter WWI broke out, followed by the I9I7 Revolution, and all this glory and beauty perished.

\section{THE PARTS OF THE BISHOP'S ROBES}

The bishop's vesting ceremony that von Gardner recalls consists of the following principal steps: the bishop arrives in the church dressed in his black monk's cassock and is met by priests and deacons. Two of the latter remove his black mantle and dress him in a colorful bishop's mantle. He is then escorted to a raised platform in the middle of the church known as the vesting place. The mantle is removed, and he is dressed in his robes in the presence of the congregation with the help of a deacon, also in robes, on either side of him. The vestments are brought forth on a large tray from the altar room by another deacon. Throughout the ceremony, one of the deacons blesses it with incense in a censer. The vestments consist of seven parts, the most important of which are the sakkos, the omophorion, and the miter. The ritual begins with the deacon who brought the vestments reading and the choir singing the Marian hymn „It is Worthy to Praise,” followed by a recital and chant of a text from Isaiah in which the first person pronoun has been replaced by the second:

Thy soul shall rejoice in the Lord,

for He has clothed thee with the garment of salvation

and covered thee with a tunic of happiness;

He has crowned thee as a bridegroom

and as a bride, adorned thee with jewels.

(Isaiah 6r:IO)

The bishop kisses and blesses the various parts of the robes with the sign of the cross before they are put on him. The ceremony concludes with a symbolic washing ritual and the bishop blessing the congregation with two candlesticks, one with two candles (the dikirion), and the other with three (the trikirion). Some of the symbolism of the vestments is interpreted for the congregation in the course of the dressing ceremony, although it may be difficult to understand what is read and sung in Church Slavic, the liturgical language used by the Russian Church. What von Gardner describes in particular is the wonderful singing and beautiful movements in the ritual. At times the 
aesthetics of the Orthodox Church is reminiscent of the classical Russian nineteenth-century ballet. The Russian priest and religious philosopher Pavel Florenskij, for example, speaks of the „choreography” of the Orthodox service ${ }^{2}$. Von Gardner also notes that the ceremony is a manifestation of an ancient pious tradition. Despite what he says about its fate, however, it is very much alive today. The ritual is performed by the other Orthodox churches as well, albeit not with the intensity and beauty of the Russian tradition.

The vesting of the bishop represents the climax of the Orthodox liturgical Gesamtkunstwerk that unites song, visual and tactile impressions, incense, and movement. In his article "The Church Ritual as a Synthesis of the Arts" (,Храмовое действо, как синтез искусств”), Florenskij notes this fusion of all the art forms. The ceremony is extraordinarily complex, and each detail contains often several and sometimes many meanings.

The bishop functions in the Divine Liturgy as a Christ icon that is shown in several ways during the vesting ritual and other parts of the divine service. Every aspect of dressing and undressing is significant and theologized. The most important detail in the vestments is the long band over the bishop's shoulder known as the omophorion. It symbolizes the lost sheep that the Christ the good Shepherd carries on his shoulders. This meaning is revealed to the congregation when the deacon reads the following verse during the vesting: "When Thou hadst taken upon Thy shoulders human nature which had gone astray, O Christ, Thou didst bear it to heaven, unto Thy God and Father, always, now and ever, and unto the ages of ages. Amen"4.

Liturgy interpretations are a very special and widespread genre in Orthodox theological literature. There as well - for example in the eighth-century Patriarch Germanos' work On the Divine Liturgy - there is a connection between the lost sheep and the omophorion: „The omophorion of the bishop is made of wool and not linen. For it represents the lost sheep which the Lord found and put upon His Own shoulder"s.

Besides representing a likeness of Christ, the omophorion harks back to the Byzantine emperor's ceremonial loros band or scarf and thus points to the close relationship between the ceremony and Byzantine court

\footnotetext{
2 P. Florenskij, Sobranije sočinenij, I Stat'i po iskusstvu, Paris 1985, pp. 4I-55.

3 P. Florenskij, Sobranije sočinenij, I Stat'i po iskusstvu, Paris 1985, p. 53.

4 The Divine Liturgy - Orthodox Liturgical Text, http://www.orthodoxliturgicaltext.com/ English-only/DivineLiturgyStJohnChrysostomandStBasilGreat.pdf (July 6th 2015).

5 Germanos, On the Divine Liturgy, Crestwood, N.Y., 1984, p. I67.
} 
ritual. It also marks the bishop's rank vis-a-vis the priest and deacon, who have other types of bands - the epitrchilion and the orarion, respectively as part of their vestments. Because the omophorion has three folds, it also symbolizes the Trinity. Thus each item in the garments is assigned double and sometimes multiple interpretations.
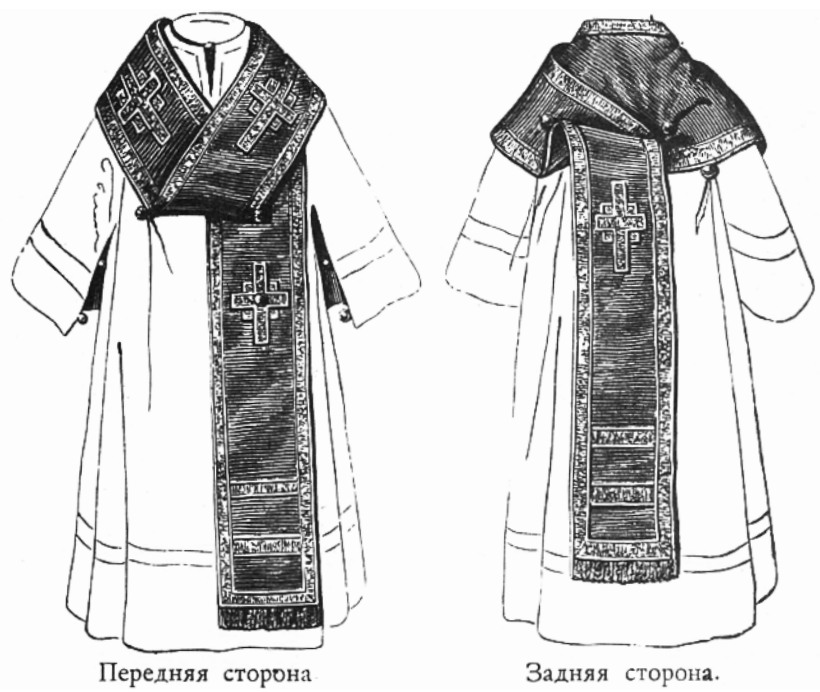

A bishop's sakkos and omophorion. Front and back

The sakkos, a sleevless, open chasuble, is also assigned several different meanings. Originally part of the imperial costume, it first began to be worn by the Patriarch in Constantinople, then by the Russian Metropolitan, and finally by all bishops. It symbolizes Christ's purple mantle. Thus there is an enormous range of interpretations involved here.

The same breadth applies to the bishop's miter, which has the form of a royal crown. It represents the crown of the ruler, the crown of thorns worn by Jesus, and also the Gospel that the bishop is about to preach. It therefore has the same embellishment as the Gospel Book (Christ, Mary, and the Evangelists).

The robe that is put on the bishop before the procession into the church represents the purple mantle that Christ was made to wear in mockery, but because it is also associated with the emperor's dress it has an imperial connotation as well. Like the sakkos, the mantle was a present from the emperor to the patriarch, and the similarity in their garments represents what the Byzantines called „symphony”: that is, the good and mutually supportive 


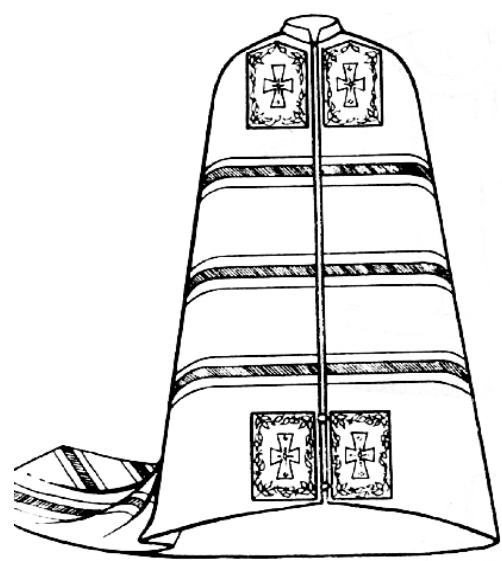

A bishop's mantle

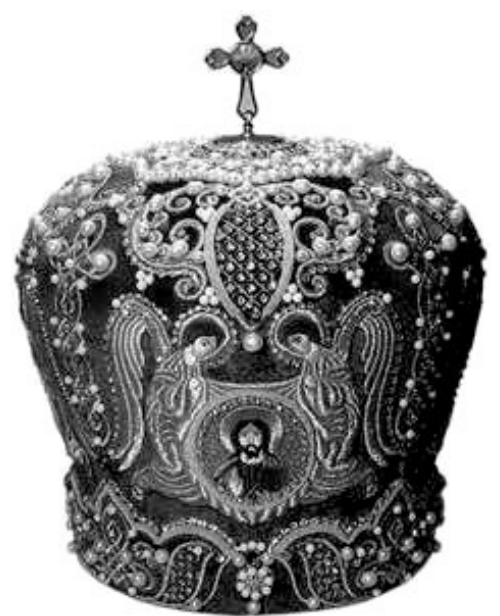

A bishop's miter

relationship between these the worldly and ecclesiastical powers. Its color depends on whether the bearer is a bishop (violet), metropolitan (blue), or patriarch (green). Two squares at the very bottom symbolize the Old and New Testaments, and the three bands of a different color running farthest up along the middle and lower part of the robe represent the Trinity and the bishop's didactic role. Called "springs" or „streams", they stand for the streams of nstruction emanating from him. Ultimately the symbolic system becomes self-generating and nearly endless. 
The vestments also convey a specific dogmatic message, for their seven parts symbolize the seven sacraments that the bishop distributes ${ }^{6}$. His garments consist of three layers that together indicate his rank: first is a deacon's cassock, on top of that the garb of a priest, and finally the items that comprise the bishop's vestments.

During the service the bishop stands on a special rug showing an eagle hovering over a cityscape. In Russian ecclesiastical usage it is called „orlets” derived from the word for eagle - „orel”. The symbolism here is multilayered: the eagle represents the bishop, and the bishop literally hovers over the city, which underscores the cosmic interpretation of his vestments and office? . During the Liturgy the procession is accompanied by servers carrying large stylized, gilded and silvered round fans, ripidia, depicting seraphim that symbolize the presence of the angels in the Divine Liturgy. The status attaching to the bishop's garments is spread throughout the church through these objects that belong to the bishop's Liturgy and the processions that it includes.

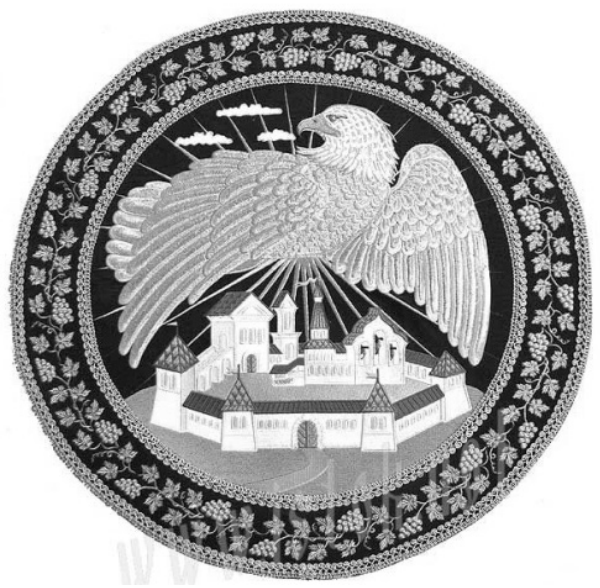

A bishop's orlets

6 Источник:http://www.pravmir.ru/svyashhennye-oblacheniya/\#ixzzzYOk6dywE(July 6th 2015).

7 „The religious meaning of the orlets depicting a city and an eagle hovering over it points especially to the high heavenly provenance and dignity of the episcopate. Standing on the orlets, it is as though the bishop is resting on the eagle; i.e., it is as if the eagle is constantly carrying the bishop. The eagle is a symbol of life in the high mountains - the celestial hierarchy”, Nastol'naja kniga svjaščennoslužitelja, Moskva 1977-1979, t. 4, pp. I07-I08. 
The imperial Byzantine element is highlighted at many points during the service when the choir chants „Many years to you, O Master” as the bishop blesses the assembly, for the Byzantine emperor was greeted with this chant whenever he appeared. The Church adopted it, and it is still sung in Russia today in the original Greek.

The ceremony also contains military metaphors ${ }^{8}$. The square piece of fabric called the palitsa in the lower part of the vestments represents not only the four Evangelists but also a sword. As it is being attached it is accompanied by the recitation of the following text (which is also read by the priest when he dons his robes, although not during any ceremony in the nave of the church):

Gird Your sword at Your side, Mighty One, in Your splendor and beauty. String Your bow; go forth, reign for the sake of truth, meekness arid righteousness. Your right hand shall lead You wonderfully, at all times, now and always and for ever and ever. Amen. (Psalms 45:4-5)

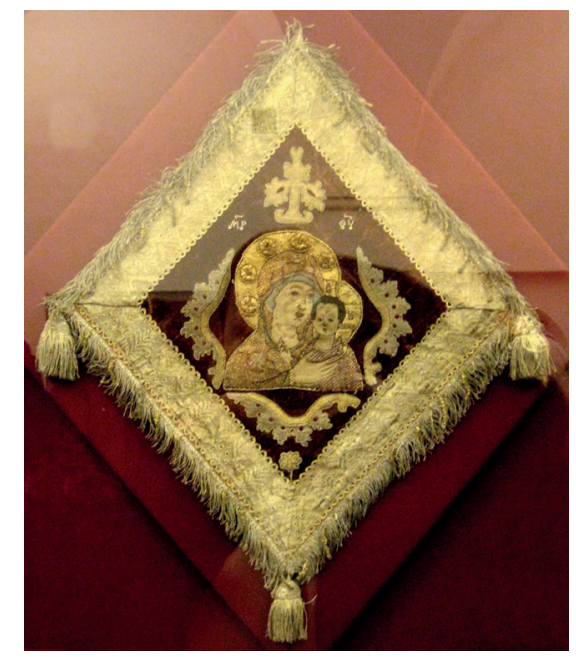

Palitsa

The vesting ritual is itself an expression of power. Only on one occasion does the bishop dress himself in public. In the Divine Liturgy on Maundy Thursday the bishop washes the feet of twelve priests. In this demonstration

8 P. Florenskij, Filosofija kul 'ta, w: Bogoslovskie trudy, Vypusk 4I, p. 22I. 
of humility he himself takes off the sakkos, the panagia medallion bearing the icon of the All-Holy Theotokos and the omophorion, and then puts them on again at the conclusion of the foot-washing ceremony.

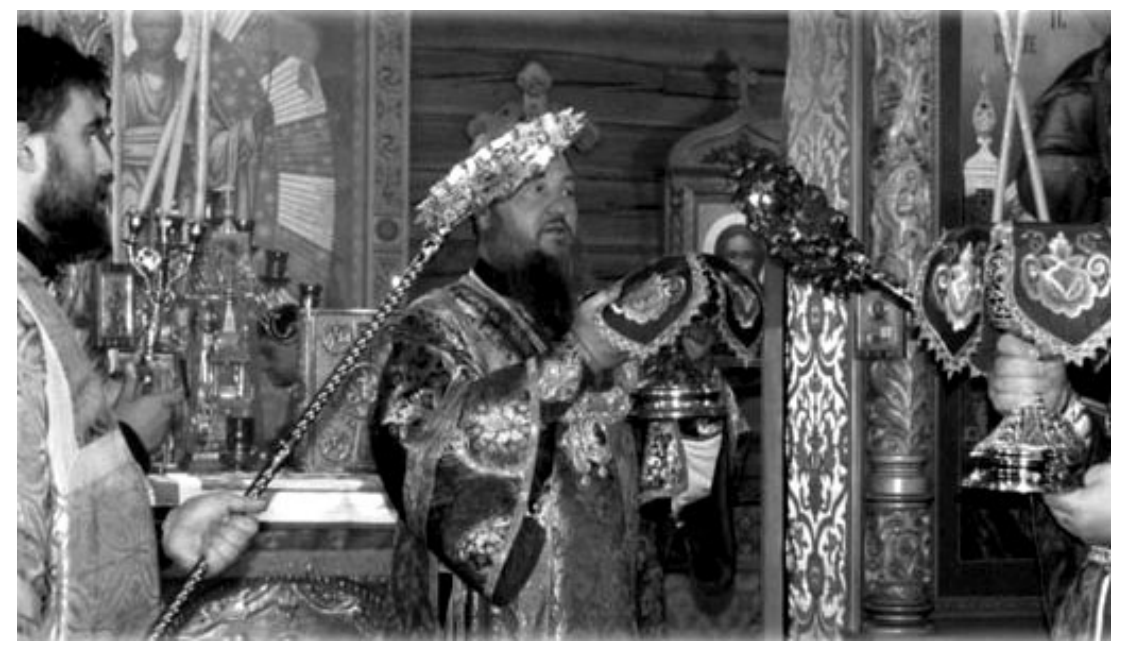

A bishop holding the chalice during the great entrance.

Note the ripidia, the dikirion and the trikirion

\section{TeXt Passages}

Various texts from the Old Testament are read during the vesting ritual, and the symbolism of the garments also echoes passages in the Bible that refer to clothing either metaphorically or in a real sense in the narratives, as, for example, when the sick touched the hem of Jesus' garment (Mat. I4:36). Exegetes note that what takes place during the ceremony is that the bishop clothes himself in Christ, thus becoming an icon of Christ. The relevant Biblical text is Gal. 3:27: „For as many of you as have been baptized into Christ have put on Christ”, which is also chanted on special occasions when the bishop blesses the congregation. The psalms use clothing metaphors as well, as here in Number I04:

Bless the Lord, O my soul.

O Lord my God, thou art very great;

thou art clothed with honour and majesty.

Who coverest thyself with light as with a garment:

who stretchest out the heavens like a curtain. 
Many Orthodox hymns use such metaphors; for example, this well-known piece that is sung during Holy Week, which alludes to the wedding feast in Matthew 22:

I see Thy Bridal Chamber adorned,

O my Saviour, but I have no wedding garment

that I may enter there.

Make the robe of my soul to shine,

O Giver of Light, and save me 9 .

In his Third Defense against Those Who Oppose Holy Images, St. John of Damascus maintains that there is a special bond between clothing and its wearer:

I have often seen lovers gazing at the garments of their beloved, embracing the garments with their eyes and their lips as if the garments were the beloved one ${ }^{\mathrm{IO}}$.

In John's metaphor the beloved is God and the fabric is the clothing in which the divine is incarnated. The vesting ritual and all of the garments in the Orthodox tradition are used metaphorically to express the believer's longing for heavenly bliss. Thus the clothing has both a real and a symbolic, or perhaps more precisely an iconic function.

\section{Aesthetics}

The text from Isaiah cited above makes it clear that the vestment has an aesthetic content. (,He has crowned thee as a bridegroom and as a bride, adorned thee with jewels"). The word used in Greek for the English ,jewels" is кó $\sigma \mu о \varsigma$ (cosmos), a word associated not only with the cosmic perspective but also with the concepts of both harmony and feminine beauty ${ }^{\mathrm{II}}$. Von Gardner's ac-

\footnotetext{
9 K. Ware, Lenten Triodion: The Service Books of the Orthodox Church, trans. by Mother Mary, London-Boston 1984, p. 527.

10 St. John of Damascus, On the Divine Images: Three Apologies Against Those Who Attack The Divine Images, Crestwood, N.Y. 1980, p. 7I.

11 S. Averincev, Poètika rannevizantijskoj literatury, Moskva [b.r.w.], p. 84.
} 
count of the bishop's Liturgy he witnessed as a youth has a counterpart in the description of the Christianization of Kievan Rus' in the medieval Chronicle of Nestor. Emissaries from Kiev traveled around to determine which religion was best suited for Rus'. They were greeted in Constantinople and invited to attend a bishop's Liturgy, and the Chronicle states that it was the beauty of this service that persuaded Kiev to adopt Christianity from the Eastern Church. The truth of this story is debatable, but what the passage demonstrates is the significance of the Bishop's Liturgy in the consciousness of the chronicler and his age:

On the morrow, the [Byzantine] emperor sent a message to the patriarch to inform him that a Russian delegation had arrived to examine the Greek faith, and directed him to prepare the church [Hagia Sophia (Greek for Holy Wisdom) and the clergy, and to array himself in his sacerdotal robes, so that the Russians might behold the glory of the God of the Greeks. When the patriarch received these commands, he bade the clergy assemble, and they performed the customary rites. They burned incense, and the choirs sang hymns. The emperor accompanied the Russians to the church, and placed them in a wide space, calling their attention to the beauty of the edifice, the chanting, and the offices of the archpriest and the ministry of the deacons, while he explained to them the worship of his God. The Russians were astonished, and in their wonder praised the Greek ceremonial.

The envoys then report on their trip to the Grand Prince:

Then we went on to Greece, and the Greeks led us to the edifices where they worship their God, and we knew not whether we were in heaven or on earth. For on earth there is no such splendor or such beauty, and we are at a loss how to describe it. We know only that God dwells there among men, and their service is fairer than the ceremonies of other nations. For we cannot forget that beauty. Every man, after tasting something sweet, is afterward unwilling to accept that which is bitter ${ }^{2}$.

Pavel Florenskij notes that the church itself is clothed in various fabrics laid on the altar and over the ambons. In Filosofija kul'ta he maintains that

12 Excerpts from Tales of Times Gone By (Povest'vremennykh let), The Russian Primary Chronicles, http://pages.uoregon.edu/kimball/chronicle.htm (July 6th 20I5). 
the vestments should be interpreted in a cosmic context, where the entire universe is the body and clothing of the soul:

clothing is cast off into the entire universe, for the entire universe is the body of the soul and its outer clothing. Hence the liturgists' attempts to explain the sacred vestments in great detail either microscopically on the basis of the makeup of the human being or macroscopically with reference to the world order ${ }^{13}$.

Thus according to Florenskij, there is a movement from the vestments through the space of the church to the entire cosmos. One example of this interpretation is the explanation of the three bands on the bishop's mantle symbolizing springs or streams of grace flowing to the bishop from all sides from the Holy Trinity ${ }^{14}$. Thus the ceremony is interpreted in aesthetic categories and is also attributed a cosmic significance. The emphasis in the Chronicle on the aesthetic content of the bishop's Liturgy and descriptions of modern observers display a very interesting and remarkable continuity.

There is a special form of performativity in the ceremony. The liturgical texts describe dressing, and that is what takes place; the texts speak of beauty, and, as is also noted in various accounts of the ritual, the ceremony is highly aestheticized. There exists a very special connection between word and deed, and constant transitions between metaphor, icon, and reality.

The ceremony embraces the entire Byzantine dimension of the Russian Orthodox Church. Concentrated within it is all the magnificent, intense solemnity that the Orthodox tradition has to offer, the grandeur and beauty that the Chronicle asserts was decisive in the decision of Kievan Rus' to adopt Christianity from Byzantium rather than anywhere else. Perhaps it was also this beauty that persuaded Johann von Gardner to devote his life to Orthodox music and ultimately himself become a bishop in the Orthodox Church.

13 P. Florenskij, Iz bogoslovskogo nasledija, w: Filosofija kul'ta, op. cit., p. 216.

14 According to the description of the mantle in Nastol'naja kniga, t. 4: „The three rows of springs|streams also signify the exceptional grace of the Holy Trinity that surrounds and covers, as it were, [the bishop] from all sides", p. I48. 
98 || Per-Arne Bodin

\section{GENDER AND TACTILITY}

The ceremony also observes a special gender order. In the text from Isaiah the bishop is called both the bride and the groom. The hymn „It is Worthy to Praise" is dedicated to the Mother of God. Yet another hymn is about the Virgin Mary. „Worthiness” is otherwise and important concept in the ordainment of deacons, priests or bishops, where it is posed ceremonially, but in the hymn it refers to the Mother of God. The medallion the bishop dons during the vesting called the "panagia” - ,the all-holy" - bears an image of her. The text read as the bishop puts on the miter is almost identical to that which is used for weddings. In interpretations of the vesting the bishop assumes both male and female features, which creates some uncertainty as to whether the hymns and liturgical texts are about Christ, the Virgin Mary or the worthiness of the bishop. One contemporary Russian Orthodox bishop associates the bishop's role in the Divine Liturgy with the woman in Revelation („And to the woman were given two wings of a great eagle'):

The orlets, the eagle on which he stands, seems to indicate the mystical heights to which he is carried (Isa. 40.3I), and reminds one of the woman in Revelation I2.I4 and of Jesus' sayings: 'where I am, there shall my servant be also' (John I2.26); and 'that they also whom thou hast given me, should be with me where I am, that they may behold my glory' (John I7.24) ${ }^{15}$.

Yet another important element of the ceremony is the constant kissing of the different parts of the vestments as they are arranged by both the bishop himself and various church servers. The ritual is very tactile in nature. The bishop's garments and all of their components have an iconic function, for they are vehicles of a holiness that according to the exegetes is on the boundary between the heavenly and the earthly. One contemporary Russian

15 Basil, Bishop of Sergievo, The Making of a Priestin the Byzantine Tradition, http://jbbur nett.com/resources/basil_sergievo_pr-in-byz.pdf(July 6th 20I5). 
theologian maintains that the vesting of the bishop signifies a transition to another reality:

and during the bishop's Liturgy you sense particularly keenly that you have entered a different, mystical reality. Everyone feels $\mathrm{it}^{16}$.

There is a special permeability of the divine in the ritual that is reminiscent of Andrej Rublev's Holy Trinity icon.

Florenskij notes that all other garments and dressing ceremonies in the name of Christ have the same divine, sacred character as the bishop's vesting, but that their degree of holiness is lower. According to him, every human act is supposed to have a sacred content and be a reflection of a divine process ${ }^{17}$.

\section{Cultural protests against the vestments}

All these liturgical garments and the gulf between Byzantine pomp and the humility ascribed to the parts of the vestments are challenged by an entirely different phenomenon in the Russian and Byzantine tradition: holy foolishness, where nakedness conveys the Christian message. Is there not something almost blasphemous about this splendor in the bishop's dress and vesting ceremonies, for when Christ roamed through Palestine he completely lacked such magnificence? This is actually the question that fools in $\mathrm{Christ}^{18}$ address to their own Christian tradition.

Foolishness in Christ is a special form of piety in the Russian and Byzantine tradition. Fools behaved offensively, sometimes threateningly, to provoke sinners to repent and better themselves, and they performed incomprehensible acts that are subsequently revealed to be prophetic. Ugly, dirty, and foul-smelling, the fool challenged the Orthodox cult of beauty. Clothes were particularly important: fools were always conspicuously dressed in filthy

\footnotetext{
16 Bezmolvnaja propoved'. Simvoly archierejskogo oblačenija, http://www.sestry.ru/ church/content/masterskie/sewing/events/8/ (July 6th 20I5).

17 P. Florenskij, Filosofija kul'ta, op. cit., pp. I96-248.

18 About holy fools see: S. Ivanov, Blažennye pochaby: kul'turnaja istorija jurodstva. Jazyki slavjanskoj kul'tury, Moskva 2005.
} 
rags and very colorful garb. They often went barefoot even in the winter and in the snow, or sometimes they would wear only one shoe. It was particularly common for them to go almost around naked in the heavily-clad reality of medieval Russia.

The behavior of the fools and the Church's interpretation of them figure in the saintly legends about them. Many have been canonized. Some of them challenged even the worthiness of the bishop by donning a metal hood and acting outrageously to ridicule the bishop and his miter. The fool Prokopij of Ustjug stood outside the church holding three pokers representing the bishop's three-pronged trikirion. Nakedness stands for innocence and the nakedness before the Fall, states a hymn to Vasilij, the fool who lent his name to the cathedral on Red Square:

Just as the sun and the moon

feel no shame for their nakedness.

So didst thou, Christ's saint Vasilij, naked, feel no shame,

for thou tookest upon thyself the robe of Adam the first created ${ }^{19}$.

While holy foolishness was a protest within the Church, Peter the Great's treatment of the bishop's vestments represented a powerful protest on the part of the secular power. He exploited the garments in two different contexts. First, to diminish the power of the Church he ordered that all bishops could wear the sakkos, not only patriarchs as previously, and he allowed certain priests to wear the miter. He also increased the number of bishops in order to dilute the hierarchical structure of the Church. His most important measure, however, was to abolish the Patriarchate. The emperor took over leadership of the Church and established a special bureaucracy to govern it - the Holy Synod.

Peter also indulged in much different behavior to lessen the power of the Church, and here as well vestments played a role. For more than 30 years he led the so called All-Drunken Synod of Fools and Jesters, which performed crude parodies of divine services with texts written by Peter himself. In reality they were drunken binges. The participants dressed as metropolitans or other ecclesiastical dignitaries in a mixture of Orthodox and Catholic vestments. The miters were Catholic, and the panagia was replaced by a pocket flask.

19 http://www.fotinya.orthodoxy.ru/akafist_Svyatim_26.html (July 6th 20I5). 
Members were inducted in a blasphemous parody in which they took an oath not to God but to Bacchus. The vesting ceremony was also lampooned:

May Bacchus' drunkenness becloud, and shake and roll and derange thee throughout thy life!" Then the ordainee fell to his knees, lay down and bowed his chest and hands and head over a barrel proffered to him and the priests sang Bacchus' song. Then he stood up and went to the ordainer on the high ambon, where the archpriests dressed him in all of his vestments except the hat ${ }^{20}$.

The bishop's vestments and the vesting ceremony are culturogenic; they constantly create new meanings and are used artistically, religiously and politically.

\section{VESTING FROM A SEMIOTIC PERSPECTIVE}

One question that arises after examining the semiotic function of clothing in the Orthodox Church concerns the identity of what Roman Jakobson calls the sender and the receiver of the message and whether or not the code is intelligible. The Biblical texts that are read during the vesting supply the meaning of certain parts of the ceremony, but many details are internal and can be understood only within the culture of the entire Church as a collective receiver. There are many layers of explanations that are accessible only to the Church as a whole or as the speculations on the part of various theological exegetes. One of the most important sources of these interpretations besides patriarch Germanos already mentioned is Symeon of Explanation of Orthodox Divine Services, Customs, and Sacraments.

Like the symbolism of folk costumes, certain details of the bishop's robes remain unexplained. Often the ritual seems to precede the interpretation, much as a work of art is created before it is analyzed.

The permeability or transformation of the person being dressed is intelligible to all as the penetration of ,another reality" into the realm of „the ordinary". As is evident from almost all of the quotations cited above,

${ }_{20} \mathrm{~N}$. Evreinov, Istorija russkogo teatra: s drevnejšich vremen do I9I7 goda, N'ju-Jork I955, p. 477. 
I02 || Per-Arne Bodin

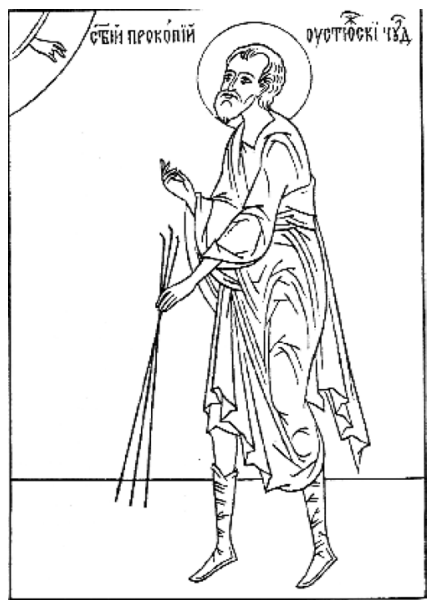

The fool Prokopij of Ustjug with three pokes

the aesthetic impression of the ceremony as a whole both seems conveyable and really is communicated to the viewers. Who, then, can be considered the sender and receiver of the information sent through the bishop's vestments and the vesting ceremony? As in the events of the Divine Liturgy in general, there are two linguistic or communicative levels in the ritual: one is between God and humans, but there is also a dialogue between the Church and the congregation. The message that is mediated to God is understood by the congregation to be the word of the Lord, so the answer is perhaps that it is God who is both sender and receiver, while the congregation is a co-listener.

Few if any parishioners are aware of the rich body of works that interpret various ecclesiastical ceremonies. Sermons explaining the symbolism are rare. In general, such explanations function much like scholarly analyses of literary works.

The role of clothing and nakedness belongs to an iconic view of not only the images but also the Divine Liturgy as a whole that pervades all services in the Orthodox Church. The bishop represents Christ, and many interpretations of the details of his garments have to do with that fact.

What is common to both the vesting of the bishop and the opposite behavior of the fools in Christ are the iconic function of clothes or the lack thereof and their thoroughly semioticized mode of expression. The abundance of clothing, nakedness, and cross-dressing (in the case of certain holy fools) can be ascribed the iconic function of representing the reality of the kingdom of heaven. 


\section{Vestments, CUlture AND POLITICS}

Bishop and patriarch vestments acquired additional meanings during the Soviet period. A poem by one of the greatest twentieth-century Russian poets, Osip Mandelstam, compares the poet's fate to recently enthroned Patriarch Tichon in a poem written the year after the revolution, in I9I8. Like the globe on Atlas' shoulders and the miter worn by the new patriarch, the world weighs heavy on his head:

Who knows, maybe my candle won't last, and right in broad daylight I'll drop into night, and breathe scattered poppy seeds and wear a black mitre on my head:

Like the dilatory patriarch, in ruined Moscow, unconsecrated world on my head, racked with argument, blind, blind like Tikhon - the elected by the last church-council ${ }^{21}$.

Pavel Korin, one of the best-known Russian artists in the Soviet Union, painted an unfinished canvas during the Stalin era entitled Requiem depicting a memorial service in the Uspenskij Cathedral for Patriarch Tikhon attended by a number of bishops in full regalia. It was a Divine Liturgy in the same cathedral that von Gardner described with such emotion. There was in fact no such memorial service there upon the Patriarch's death in 1925, for the church had been closed by the authorities. Korin attended Tichon's funeral, but that took place in the cathedral of the Donskoj Monastery. Korin's painting is a composite of various churches and events, among them the last Liturgy celebrated in the Uspenskij Cathedral at Easter 19I8. There were no more services celebrated there until I990, more than seventy years later. Korin was attempting with his picture to evoke a Russia that no longer existed, perhaps something of the Russia to which von Gardner dreamed himself back as an émigré.

${ }^{21}$ O. Mandelštam, Complete Poetry of Osip Emilevich Mandelstam, Albany, N.Y. 1973, p. 172. 
I04 || Per-Arne Bodin

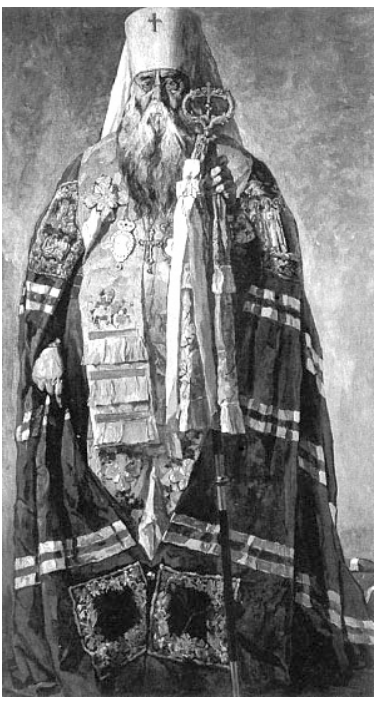

In another painting he depicted the metropolitan Sergij in his mantia. The painting was made in the 1930-ies when the church was almost anhilated, but in spite of that fact Sergij appears to be a powerful church-leader. The painting becomes a token that the church will survive.

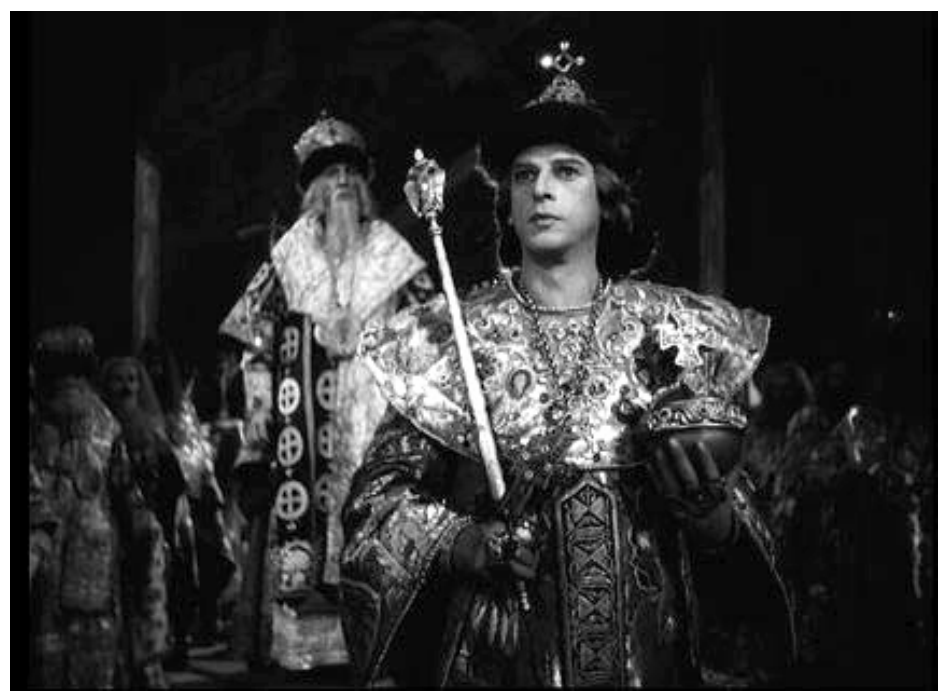


The bishop's garments also acquired a political meaning in both parts of Sergej Eisenstein's film Ivan the Terrible. The first part of the film shows Metropolitan Pimen in his vestments standing on the vesting place and crowning Ivan with the fur-brimmed hat signifying the might of the tsar. Their power and the relationship between them is expressed through their clothing. In the second part of the film there is a dramatic scene in which another church leader metropolitan Filipp refuses to give the tsar his blessing. Ivan in a monk's cassock and the metropolitan in his vestments walk toward each other and meet in the center of the church. The Patriarch's special vesting place with the eagle rug stands out in the center of the picture. He is dressed in his legitimate vestments, whereas Ivan is falsely clad in the garb of a monk. The contrast between the clothing of the pair partly accounts for the tension in the scene. Filipp was deposed and murdered by the tsar when he criticized the terror that Ivan perpetrated together with his oprichnikik henchmen.

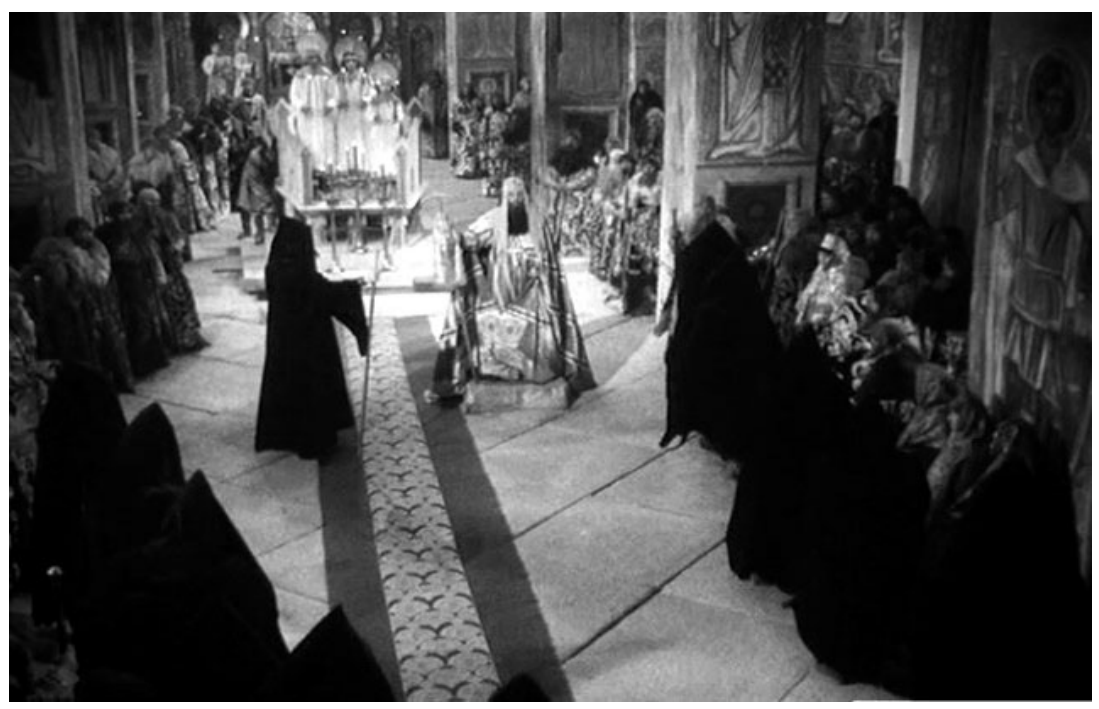

Russian TV audiences had two opportunities to see bishop's vestments when Patriarch Kirill was enthroned in 2009: when he arrived at the Christ the Savior Cathedral, and again during the vestment of him as patriarch later in the service. 


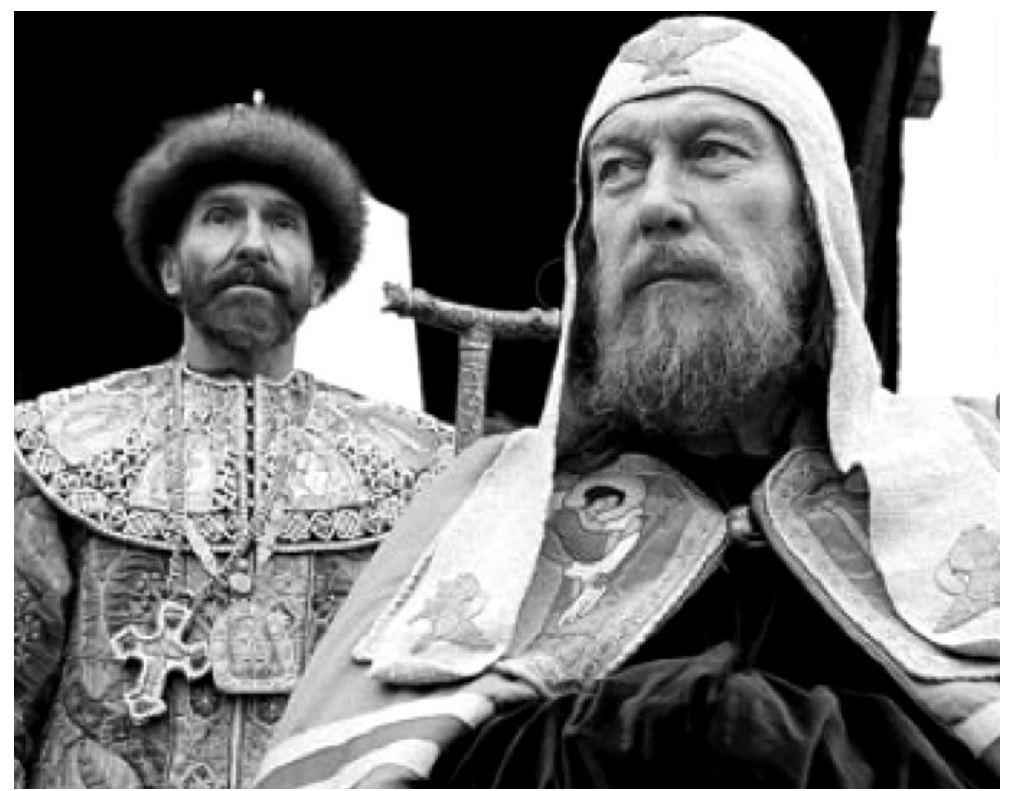

Also in 2009, Pavel Lungin's film The Tsar had its premiere. It is about Ivan the Terrible and his conflict with Metropolitan Filipp. As in Eisenstein's film, there is a scene in which Filipp refuses to bless Ivan. The clash between them is shown through first the vesting of the tsar in garments that indicate his position followed by an episode showing Filipp's enthronement. In the scene where the metropolitan refuses his blessing the Tsar tears the miter from his head and stamps on it. One of his henchmen rips off the Metropolitan's

sakkos and the tsar physically assaults the head of the Church. The conflict between Church and State in this scene is a far cry from the cooperation that characterizes Patriarch Kirill and President Putin's current relationship.

Lungin consulted several representatives of the Russian Orthodox Church as advisors. Every morning a prayer service addressed to Metropolitan Filipp was held on the set. Here the border between film and reality, or rather between the film and a liturgical act was almost erased, and the proximity of the actual enthronement that same year made itself felt. Because the film poses the same question as the enthronement of the patriarch on the relationship between the spiritual authority of the Church and the secular power of the State, it was perceived as a contribution to the ongoing debate on the subject. Both phenomena, albeit to different degrees, were orchestrated by 
the Church. Some critics interpreted the vesting of the tsar as a parody of the bishop's ceremony meant to mock the Church, whereas others viewed the film as criticism of the totalitarian evolution of the current regime

The vesting of Ivan in the film The Tsar is reminiscent of the vesting of the Pope in Bertolt Brecht's Life of Galileo, a scene in which as Cardinal Barberini is clothed in layer after layer of robes he increasingly becomes a part of the Church and finally approves threatening Galileo with torture. Lungin's film contrasts the robes of the tsar and the patriarch on several occasions. The conflicts between these two centers of power are enacted not only in words and deeds, but also through sartorial imagery.

Thus the enthronement ceremony and its various components possess considerable potential significance in modern Russian culture as well. The nature of political violence and autocracy and the relationship between Church and State are expressed in the presentation of the ritual both in reality and through film. The bishop's vestments and his vesting are an important theme not only in the history of the Russian Church but also in Russian culture. Despite years of persecution of the Church and coerced atheism, they are still potentially very meaningful. They can convey a message about the existence of a different, divine reality, but they can also say something about the relationship between Church and State or between the poet and history.

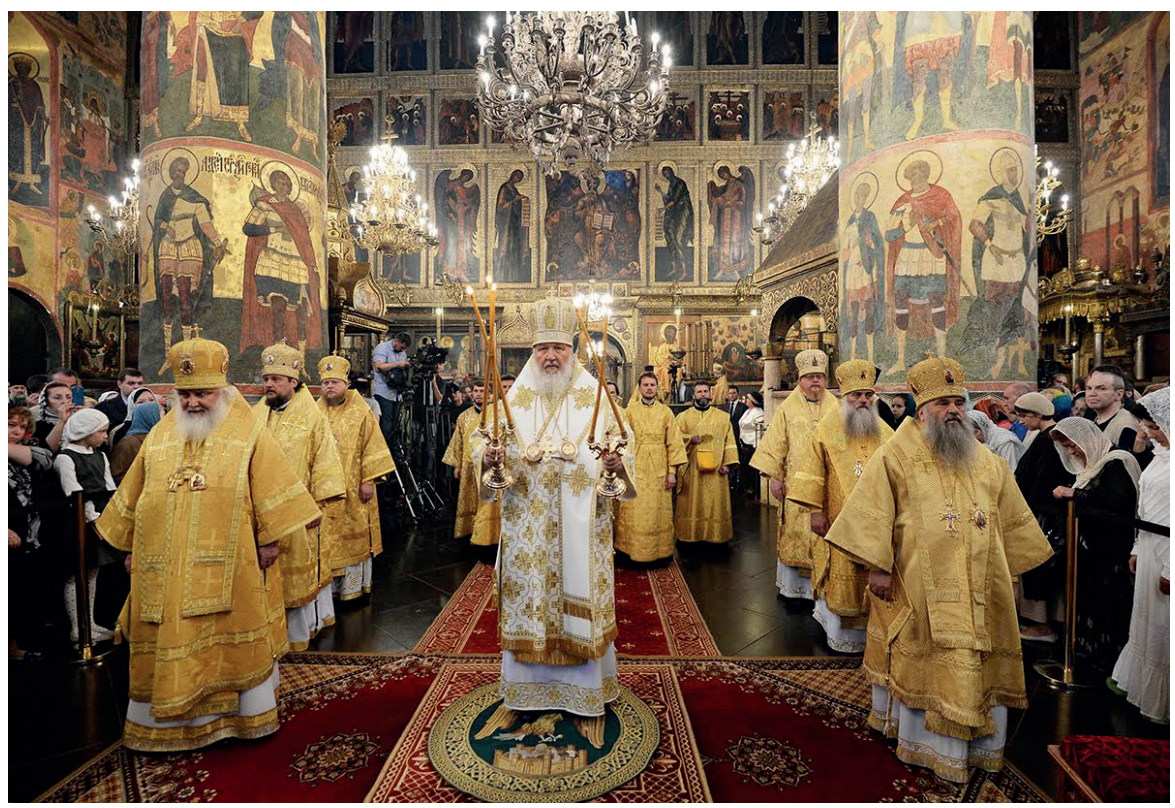


I08 || Per-Arne Bodin

\section{REFERENCES}

Averincev S., Poètika rannevizantijskoj literatury, Moskva I977.

Basil, Bishop of Sergievo, The Making of a Priestin the Byzantine Tradition, http://jbburnett.com/resources/basil_sergievo_pr-in-byz.pdf(July 6th 20I5).

Bezmolvnaja propoved'. Simvoly archierejskogo, http://www.sestry.ru/ church/content/masterskie/sewing/events/8/ (July 6th 20I5).

Chupungco, Anscar J. (red.), Handbook for Liturgical Studies, Collegeville, Minn., I997-2000, p. I Introduction to the Liturgy.

The Divine Liturgy - Orthodox liturgical text, http://www.orthodoxliturgicaltext.com/English-only/DivineLiturgyStJohnChrysostomandStBasilGreat.pdf July 6th 2015

Germanos I, On the Divine Liturgy, Crestwood, N.Y., 1984.

Grimes R. L., The Craft of Ritual Studies, Oxford 2014.

Florenskij P., Sobranie sočinenij, I. Stat'i po iskusstvu, Paris I985.

St. John on Damascus, On the Divine Images: Three Apologies against those who Attack the Divine Images, Crestwood, N.Y. I980.

Excerpts from Tales of Times Gone By (Povest'vremennykh let), The Russian Primary Chronicles, http://pages.uoregon.edu/kimball/chronicle.htm (July 6th 20I5).

Donovan K., "Liturgy and Communication", The way I972 . No. 2, pp. 9I-98. http://diak-kuraev.livejournal.com/4386I.html (July 6th 20I5).

Florenskij P., Filosofija kul'ta, w: Bogoslovskie trudy, Vypusk 4I, pp. 196-248. http://www.religare.ru/2_27530.html (July 6th 20I5).

Istorija russkogo teatra, Moskva $20 \mathrm{II}$.

Ivanov S., Blažennye pochaby: kul'turnaja istorija jurodstva. Jazyki slavjanskoj kul'tury, Moskva 2005.

Mandel'štam O., Complete Poetry of Osip Emilevich Mandelstam, Albany, N.Y. 1973.

Nastol'naja kniga svjaščennoslužitelja, t. 4, Moskva I977-I979.

Mother Mary (Translator), K. Ware, Lenten Triodion: The Service Books of the Orthodox Church, London-Boston I984.

The Triumph of Orthodoxy, http://www.pravoslavie.ru/english/69I22.htm (July 6th 20I5).

Woodfin W. T., The Embodied Icon. Liturgical Vestments and Sacramental Power in Byzantium, Oxford $20 \mathrm{I} 2$. 